\title{
8
}
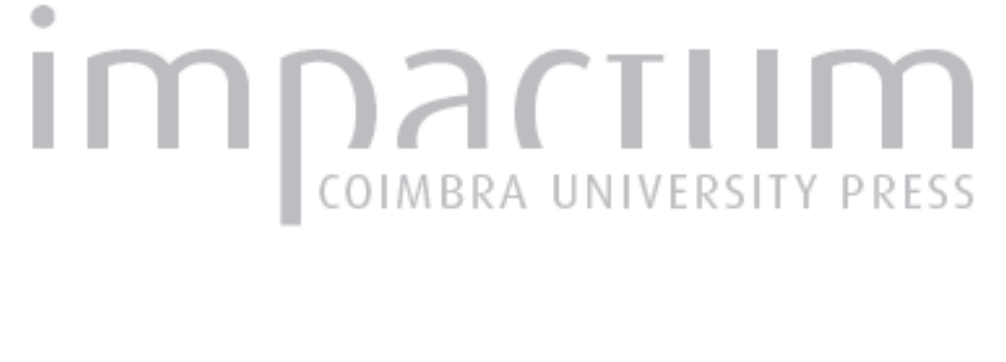

\section{Enkrateia: Plutarch on self-control and the politics of excess}

\section{Autor(es): $\quad$ Smith, Margaret DeMaria}

Publicado por: International Plutarch Society

URL persistente:

URI:http://hdl.handle.net/10316.2/37576

DOI:

DOI:http://dx.doi.org/10.14195/0258-655X_1_6

Accessed : $\quad$ 26-Apr-2023 15:00:08

A navegação consulta e descarregamento dos títulos inseridos nas Bibliotecas Digitais UC Digitalis, UC Pombalina e UC Impactum, pressupõem a aceitação plena e sem reservas dos Termos e Condições de Uso destas Bibliotecas Digitais, disponíveis em https://digitalis.uc.pt/pt-pt/termos.

Conforme exposto nos referidos Termos e Condições de Uso, o descarregamento de títulos de acesso restrito requer uma licença válida de autorização devendo o utilizador aceder ao(s) documento(s) a partir de um endereço de IP da instituição detentora da supramencionada licença.

Ao utilizador é apenas permitido o descarregamento para uso pessoal, pelo que o emprego do(s) título(s) descarregado(s) para outro fim, designadamente comercial, carece de autorização do respetivo autor ou editor da obra.

Na medida em que todas as obras da UC Digitalis se encontram protegidas pelo Código do Direito de Autor e Direitos Conexos e demais legislação aplicável, toda a cópia, parcial ou total, deste documento, nos casos em que é legalmente admitida, deverá conter ou fazer-se acompanhar por este aviso.

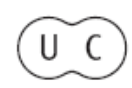




\title{
Enkrateia: Plutarch on Self-Control AND THE POLITICS OF EXCESS \\ by \\ Margaret DeMaria Smith \\ University of California at Irvine
}

\begin{abstract}
Whether Plutarch made programmatic statements about the moral themes of the Lives or used exemplars to make his point, he relied upon a lingua franca of moral virtues held in common with his audience. Antony and Demetrius failed as leaders, according to Plutarch, because of their primary character flaw, akrasia (lack of selfcontrol). To Plutarch and his audience, enkrateia (self-control) was not simply the opposite of akrasia but part of a nuanced continuum of behavior. This essay briefly examines how Plutarch's lingua franca of self-control is defined in the Moralia and deployed in the Lives of Alexander, Demetrius, and Antony.
\end{abstract}

In a word, Antony wronged himself by his lack of self-control (akrasia), while Demetrius wronged others.

(Compar. Demetr et Ant. 4.6.1)

Plutarch announces in the prologue to his Lives of Demetrius and Antony that these biographies were offered as cautionary tales, "...so," as he states, "...we shall be more eager to observe and imitate the better lives if we are not left without lives that are blameworthy and bad" (Demetr. 1.6). Specifically, Plutarch warns against the many great vices visible in lives of excess. He characterizes Demetrius and Antony as lusty, heavy drinkers who went to war on the slightest pretext, who were too freehanded with their money and arrogant as well ${ }^{1}$. For Plutarch, these excesses had one outcome, namely, reversals of political and military fortune, and one cause: the lack of self-control (akrasía). However since the Lives of Demetrius and Antony are cautionary tales, they do not discuss the virtue of self-control per se. In fact, the word enkrateia does not occur in either life and its opposites akrasia and akolasia occur but rarely in the biographies of Antony and Demetrius. This fact should not be surprising since, as Duff points out, Plutarch usually leaves moral judgments implicit and allows the exempla presented in the

1 É

PLOUTARCHOS, n.s., 1 (2003/2004) 79-88. 
Lives to speak for themselves ${ }^{2}$. Nevertheless, Plutarch's silence has not deterred Harrison from identifying enkrateia as the 'pre-eminent virtue' that provides the moral focus for the Lives of Demetrius and Antony ${ }^{3}$.

Since Plutarch's primary audience for the Lives consisted of his friends who often were navigating the offices of the Imperial cursus honorum ${ }^{4}$, the author could then rely upon the cultural knowledge shared by these men. As Stadter has demonstrated, the moral program of the Lives is not rule-based, rather it achieves paideia through observation and mirroring of the protagonists behavior $^{5}$. Therefore Plutarchan paideia in the Lives relies upon the lingua franca of moral virtues that the audience members brought with them from their primary education in philosophy and rhetoric. This essay will examine that Plutarchan lingua franca concerning self-control and its absence as discussed in the Moralia. We will then turn our attention to the deployment of the language of self-control in Plutarch's Lives of Demetrius, Antony, and for comparison's sake, Alexander to examine how these terms are used to underscore programmatic statements ${ }^{6}$.

Plutarch discusses enkrateia at length in De Virtute Morali ${ }^{7}$ and follows Plato and Aristotle in the belief that virtue $(\hat{e} t h o s)^{8}$ is not monolithic; rather it possesses a "two-fold nature" (De Virtute Morali 441). These two components of virtue (êthos) are called the Rational (logos) and Irrational (to alogon). Virtue is produced by the action of Reason on the Irrational part of the soul. Reason cannot and does not eradicate passion completely; rather, it places order and limitation on the irrational through the exercise of prudence (phrônesis). Within this operational frame-
7 Especially the idea that virtue is really one, uniform concept with many names depending upon on the situation.

Tim Duff, Plutarch's Lives: Exploring Virtue and Vice, Oxford: OUP, 2000, p. 6.

George W. M. Harrison, "The Semiotics of Plutarch's $\Sigma v \gamma \kappa \rho i ́ \sigma \in ı$ : The Hellenistic Lives of Demetrius-Antony and Agesilaus-Pompey", Révue Belge de Philologie et d'histoire, 73.1 (1995), p. 92.

Philip A. STADTER, "The Rhetoric of Virtue and Vice in Plutarch's Lives", in LuC VAN Der Stockt (ed.), Rhetorical Theory and Praxis in Plutarch, Louvain: Peeters, 2000, pp. 495-7. Stadter argues against a student audience for the Lives and provides a thorough list and description of the men who embodied Plutarch's primary audience.

STADTER, 2000, pp.504-5.

This essay is excerpted from the author's longer survey of the use of the term enkrateia throughout Plutarch's works.

Plutarch refers to virtue as êthos in this section of De Virtute Morali. 
work, Plutarch constructs a continuum for the virtue of self-control (sophrosune, enkrateia) and its absence (akrasia, akolasia) based on Aristotle's Nicomachean Ethics.

Sophrosunê (temperance) is the ultimate form of self-control, according to Plutarch. He defines the term using an equestrian metaphor borrowed from Plato's Phaedrus:

But the fact is that temperance (sophrosunê) belongs to the sphere where reason guides and manages the passionate element, like a gentle animal obedient to the reins, making it yielding in its desires and willingly receptive of moderation and propriety...

(De Virtute Morali 445b)

Sophrosunê, although involving a confrontation between the rational and irrational elements of the soul, implies a soul so disciplined and well educated that the passionate elements of the irrational part of the soul are quickly brought into harmony with Reason.

On the other hand, a certain lack of harmony between reason and passion consigns enkrateia (self-control) to the status of being, "...less than a virtue" (De Virtute Morali 445d). Plutarch quotes Aristotle who in Nicomachean Ethics ${ }^{9}$ declares that enkrateia is not a virtue because it is "...a mixture of virtue and vice" (Ethica Nicomachea, 1128b 33) ${ }^{10}$. Again, Plutarch borrows the charioteer metaphor from Plato's Phaedrus to explain the working of enkrateia:

...the self-controlled man,
while he does indeed direct his
desire by the strength and mas-
tery of reason, yet does so not
without pain, nor by persua-
sion, but as it plunges sideways
and resists, as though with
blow and curb, he forcibly sub-
dues it and holds it in, being the
while himself full of internal
struggle and turmoil.
(De Virtute Morali $445 b-c)$

The engkratês, or self-controlled man, may act in the same manner as the person possessed of sophrosunê but appearances are deceptive. The greater inner turmoil of the enkratês (self-controlled man) signals a lack of education, or failure of paideia. Reason may be stronger than Passion in the case of the enkratês but not by much. Thus, the enkratês, lacks inner peace.

Plutarch alludes to the end of section iv of the Nicomachean Ethics where Aristotle discusses virtuous action and that to be called virtuous, an action must lack conditionality. For a full and highly nuanced discussion of enkrateia, see section vii of the Ethica Nicomachea.

10 This would seem to complicate Duff's argument that akrasia is a vice because it lacks the mixing of virtue and vice required to achieve moderation. Duff takes akrasia to mean both lack of self-control (akrâsia) and lack of mixing (akrasia). See Tim DufF, Plutarch's Lives: Exploring Virtue and Vice, Oxford: OUP, 1999, p.92. 
Plutarch discusses two aspects of the lack of self-control, akrasia (the absence of restraint) and akolasia (intemperance) in much the same manner. Akolasia is a full on vice, but akrasia is something less. In the process of akrasia, “...reason argues against the passions as it follows them" (445e). While the soul "...with the aid of reason, preserves its power of judgment intact, yet by its passions, which are stronger than its reason, it is swept along against its judgment" (De Virtute Morali 445e). Akrasia, as understood by Plutarch, is the sole province of neither the wise man (sophos) nor the fool. Rather, akrasia (lack of restraint) "...is the mark of the sophistic soul, which has, indeed, reason, but reason which cannot stand firm by its own just decisions" (De Virtute Morali 446c). The sophistic soul is skilled in argument but it is weak and fails to win its case against the passions.

In the case of akolasia (intemperance), Plutarch says, "...reason does not even fight" against Passion (De Virtute Morali 445e). Reason becomes the ally and advocate of dishonorable behavior in the case of intemperance. "It is character- istic of intemperance," Plutarch declares, "that its reason shares joyfully in the indiscretions committed....reason is willingly swept along into shameful conduct" (De Virtute Morali 445e). The intemperate person (akolastês) is free of remorse.

In summary, sophrosune, as an ultimate virtue, belongs to the realm of philosophy where paideia renders reason strong and passions compliant. Akolasia, on the other hand characterizes degraded human behavior that is not merely bereft of reason, but rather supported by the very faculty that should be opposing it. That leaves enkrateia and akrasia_somewhere in the middle, less than virtue, less than vice.

Plutarch raises the topic of self-control and its paideia recurrently throughout his essays. This almost-virtue surfaces in discussions of how one ought to listen properly, healthy eating and drinking, parenting, marriage, lamentation, and how to avoid talking too much. Enkrateia is not limited to human beings but is abundantly demonstrated by members of the animal and insect kingdoms ${ }^{11}$ as well. Plutarch does not explain how insects or animals train themselves to be more self-con-

11 Plutarch tells us that animals demonstrate enkrateia in their parenting abilities (De amore prolis). In De sollertia animalium (966b8), he points to their enkrateia as proof that animals have the power to reason. In the same essay, he tells us that ants demonstrate the "seeds of temperance (enkrateia), prudence (phronêsis), and justice (dikaiosunê)." (De sollertia animalium 967d 11) He considers the enkrateia of dogs to be so commonly well recognized that he is embarrassed to even mention it (De sollertia animalium 969). Sexually, the enkrateia of animals is seen in the fact that they only mate with their equals, and never desire to mate with their betters (Bruta animallia ratione uti_988-9). 
trolled $^{12}$. But for humans, enkrateia is a kind of intelligence ${ }^{13}$ that must be developed through training from an early age. For example, such early training will prevent one from becoming a busy body ( $D e$ curiositate 520d 5) and listening with self-control will ensure that a student become a philosopher and not a sophist ${ }^{14}$.

The paideia of self-control is most commonly illustrated in the Moralia with regard to food, whether or not the subject is eating ${ }^{15}$. In the essay $D e$ Genio Socratis, which is primarily a discussion of justice, the Pythagorean training method for learning self-control is described. Plutarch reports that it was customary to exercise until ravenous, return home where a feast was being prepared and then to turn the feast over to one's servants while restricting oneself to more modest fare. The benefits extended beyond physical health. As Plutarch summarizes, "For abstention from pleasure in what it allowed is a training of the soul to resist what is forbidden" (De Genio Socratis 585).
Self-controlled speech receives attention in at least three of the Moralia $^{16}$. "Just as lust ruins men, so loose talk destroys cities," Plutarch reminds us (De garrulitate 505). It is a virtue that requires extensive training (askêsis), is very difficult to achieve except by one's love of very hard work (philoponia) in mastering the emotions. Plutarch provides famous and dramatic examples of women and men who demonstrate enkrateia in speech. He reminds his audience that Odysseus' men demonstrated great self-control when they preferred "to be eaten raw" by the Cyclops rather than denounce Odysseus or reveal the plot to for escaping the cave. Plutarch call this, ".. an example of self-control and loyalty not to be forgotten" (De garrulitate 506b 10-11).

Leaena, Aristogeiton's mistress, exemplifies the political ramifications of the enkrateia of speech for Plutarch. She was party to the conspiracy against the tyranny of Hippias and Hipparchus

In De Alexandri Magni fortuna aut virtute (343a 3), Plutarch says that Alexander was naturally endowed with enkrateia, among other virtues, by the god who fathered him.

13

14

15

16

De Fortuna 97e8-15.

As Plutarch says, "...the man who has the habit of listening with restraint and respect takes in and masters a useful discourse, and more readily sees through and detects a useless or false one, showing himself thus to be a lover of truth and not a lover of disputation, nor forward and contentious." (De recta ratione audiendi 39c9-d2).

Aristotle would have agreed with Plutarch on this matter since he believed that the only behaviors in which enkrateia could rightly be exercised were with regard to eating and sex (Ethica Nicomachea 3.10,8).

De capienda ex inimicis utilitate (90b), De fortuna (97e), De garrulitate, passim. 
at Athens. After the coup was thwarted and Aristogeiton and his co-conspirator Harmodius were killed, Leaena was commanded to reveal the names of others who may have escaped detection. She remained silent and steadfast. The Athenians honored her self-control in the face of interrogation and tyranny, they

...made and set up a statue of a bronze lioness without a tongue in the gates of the Acropolis, representing by the spirited courage of the animal, Leaena's invincible character, and by its tonguelessness her power of silence in keeping a sacred trust secret.

(De garrulitate 505e1-f1)

This example reinforces the political importance of self-control as well as providing recognition of a woman's ability to achieve this level of self-discipline. Therefore as this representative sample of exempla from the Moralia indicates, enkrateia, for Plutarch, although it is a less than perfect virtue, is nevertheless a sign of paideia. It exists simultaneously as both a private and a social virtue that carries personal and political ramifications.

The term enkrateia occurs in several Lives $^{17}$, but in no life more frequently than that of Alexander. Alexander was famous for the pure virtue of sophrosune but his self-control over his gustatory and sexual appetites were thought to be part of his ability to rule well. Plutarch praises Alexander, at several points in the text, for his self-control in the face of food and $\operatorname{drink}^{18}$ (Alex. 22.7.1, 23.9.1). Alexander believed that demonstrations of his selfmastery made him more kingly (basilikôteros), "He considered it a more kingly thing (basilikôteron) to control himself than to conquer his enemies" (Alex. 21.7). For example, after a long ride with his cavalry Alexander encounters Macedonians carrying water and who offer him a drink in front of his men. Alexander refuses because he does not want to dishearten his troops. His action has the desired effect; his troops are so inspired by Alexander's abstemiousness that they continue their way with renewed fervor, "...declaring that they would not regard themselves as weary, or thirsty, or as mortals at all, so long as they had such a leader" (Alex. 42.9-10).

Plutarch reminds his readers of Alexander's sexual restraint in dealing with female prisoners on at least three occasions and each time the example given is the same. Plutarch relates that when Stateira and her daughters were Alexander's hostages, they were treated well and remained untouched by both Gracchus, Agis and Cleomenes, Aratus, Alexander. have filled his cup repeatedly but did not drink nearly as much as people thought he did (Alex. 21). 
Alexander and his men (Alex. 21.11; 30.11). These two examples (derived from a longer list of occurrences) demonstrate that enkrateia, as one of Alexander's many virtues, established his fairness as a ruler and as a warrior.

In the Life of Alexander, akolasia (intemperance) is part of a demonstration that epitomizes the moral framework set out in De virtute morali and reveals Alexander as the exemplar of sophrosunê and enkrateia. The adjective akolaston is used by Plutarch to describe Bucephalus in the famous first encounter between the young Alexander and his horse (Alex. 6). Like the wild horse of desire described by Plato and Plutarch, Bucephalus is all untamed energy. That is, until Alexander tames him. In the taming of Bucephalus we see Alexander acting as pure Reason does in De virtute morali by bringing passion under control. In this case, Alexander tames the wild and uncontrolled horse "agrion kai akolaston" (Alex. 6.2).

Although the Lives of Demetrius and Antony repeatedly demonstrate their failure to control their behavior and all the political ramifications attendant on akrasia and akolasia, it is interesting to note that these two terms rarely if ever show up in their Lives and when they do, they are used somewhat differently than described in De virtute morali. Demetrius Poliorcetes, with respect to his sex- ual behavior especially, seems to be the ultimate example of the akolastês who pursues pleasures without any internal arguments and who does not care about the effects of his pursuits on others. Plutarch narrates more than one event in which Demetrius demonstrates the sexual violence that was commonly associated with tyrants ${ }^{19}$. However, the term most descriptive of Demetrius does not surface in the text of his life. Akrasia is the term used to describe his liaison with Cratesipolis prior to a battle with Cassander's garrison in Megara. On this occasion, Demetrius left his troops in the field at Megara to detour to Patrae for the affair. Cassander's men learned of the tryst, attacked and carried off Demetrius' belongings and tent, while Demetrius escaped in shabby clothes (Demetr. 9.34). Comic relief to a battle ultimately won perhaps earns this incident the less harsh judgment of akrasia (Demetr. 9.4) even though Plutarch gives no indication that Demetrius gave a second thought to the possible consequences of his detour.

Antony, surprisingly, in spite of being faulted with akrasia in the synkrisis, is characterized in his biography as an akolastês: a leader whose unthinking lack of self-control has dire political consequences. Plutarch says of the Second Triumvirate that most Romans hated it and that they blamed Antony because of the uncontrolled life of plea- 
sure into which he had immersed himself upon his return to Rome (Ant. 21.12). Some fifteen chapters later in the Life of Antony, Plutarch again cites the uncontrolled beast of the Phaedrus but this time it is Antony who is the uncontrolled beast of burden (akolaston hypozugion) and it is Eros that goads him rather than taming him. Plutarch tells us that, at the point in Antony's life when many thought that his passion for Cleopatra had been soothed away by Reason, it returned even stronger. "And finally like the stubborn and unmanageable beast of the soul, of which Plato speaks, he spurned away all saving and noble advice..." (Ant. 36.2.2). What Plutarch sees as a compulsion to return to Cleopatra, again earns Antony the hatred of the Roman people. By immersing himself in a life of excesses, Antony earned the blame for what many Romans believed was tyranny and ultimately a foreign threat to Rome itself.

So why does Plutarch's synkrisis for the Lives of Demetrius and Antony say that the main problem for both men was akrasia and not akolasia? Does the different deployment of the philosophical terminology between the Moralia and the Lives indicate a change in thinking or some kind of linguistic slippage? Probably not, since the essential difference between the Moralia and the Lives lies along the fault line of theory and practice. In the case of enkrateia, it is not the theoretical terminology but rather the metaphor of Passion's un- tamed horse that unites the exempla of the Lives with the underlying framework of moral virtue. The image of the untamed horse (Passion/Desire) that resists domestication (self-control through the agency of Reason) was part of the moral lingua franca shared by Plutarch's particular audience as the result of their common paideia. There are two essential elements in the metaphor: the struggle and its outcome. The struggle between Desire and Reason places the metaphor in the center of the continuum between sophrôsunê and akolasia. The outcome of that struggle determines whether the person is categorized as an enkratês or an akolastês. It is important to underscore the observation that a person earns the pejorative epithet of akolastês based on outcome whether or not there is an internal struggle. Plutarch demonstrated that human lives are a mixture of virtue and vice. His identification of akrasía not akolasía as the problem for Antony and Demetrius creates subtly delineated portraits of imperfect men who struggle with their passions before they fail to control themselves. Plutarch's biographies of Alexander, Antony and Demetrius reflect the Aristotelian belief that no human being possesses either pure sophrôsunê or pure akolasía. In addition, akolasia implies such a degree of unmitigated evil that its cautionary value might be lost. Scarcely anyone in Plutarch's audience was likely to see himself as an akolastês in the mirroring exercise of the Lives. However, all would have experienced the inner struggles of 
enkrateia and akrasia. Plutarch uses the STAdTER, PhiliP A.,

Lives to demonstrate the politics of rein- - "Subject to the Erotic: Male Sexual Behaing in or giving in to the excesses of vior in Plutarch." In Doreen Innes, Harry desire. In the case of Alexander, enkra- Hine, Christopher Pelling (edd.) Ethics teia, although less than a virtue, demon- and Rhetoric: Classical Essays for Donald strated that he was more kingly than most. Russell on His Seventy-Fifth Birthday, Akrasia, though less than ultimate vice, nevertheless brought the label of tyrant to both Demetrius and Antony.

\section{BIBLIOGRAPHY}

ARISTOTLE, Oxford: OUP, 1995, pp. 221-236.

- "The Rhetoric of Virtue in Plutarch's Lives." In Luc Van Der Stockt (ed.)_Rhetorical Theory and Praxis in Plutarch, Louvain: Peeters, 2000, pp. 493-510.

Plutarch,

- The Nichomachean Ethics. Trans. H.

- “Alexander and Caesar." Plutarch's Lives. Rackham, Cambridge: Harvard UP, 1990.

DufF, TIM,

- Plutarch's Lives: Exploring Virtue and Vice, Oxford: OUP, 1999.

Harrison, GeOrge W. M.,

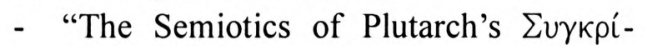
$\sigma \in \mathrm{s}$ : The Hellenistic Lives of Demetrius-Antony and Agesilaus-Pompey", Révue Belge de Philologie et d' histoire, 73.1 (1995) 91-104. Trans. Bernadotte Perrin. Vol. 7. Loeb Classical Library, Cambridge: Harvard UP, 1986.

- "Demetrius and Antony." Plutarch's Lives. Trans. Bernadotte Perrin. Vol. 9. Loeb Classical Library, Cambridge: Harvard UP, 1988.

- " On Moral Virtue." Moralia. Trans. W. C. Helmbold. Vol VI. Loeb Classical Library, Cambridge: Harvard UP, 1970. 